\author{
Volodymyr Dibrivnyi, Natalya Boutylina, Galyna Melnyk, Yurij Raevskyi \\ and Yurij Van-Chin-Syan
}

\title{
VAPORIZATION AND SUBLIMATION ENTHALPIES OF SIX CARBORANE-12 PEROXIDE CONTAINING DERIVATIVES
}

\author{
Department of Physi cal and Colloidal Chemistry, \\ LvivPolytechnic N ational University,12, S.Bandery str., 79013 Lviv,U kraine; \\ Vdibriv@polynet.Iviv.ua
}

Received: J uly 06, 2009

(C) Dibrivnyi V., Boutylina N., Melnyk G., Raevskyi Yu., Van-Chin-Syan Yu., 2010

\begin{abstract}
Vaporization and sublimation enthalpies of six peroxide containing derivatives of carboranes were obtained on the basis of temperature dependencies of the saturated vapor pressure that was measured by Knudsen effusion method. Fusion enthalpies were defined by DSC method. The inputs of carborane nuclei and the increments of the hydrogen atom deputies groups in carboranes were determined.
\end{abstract}

Keywords: carboranes, vaporization enthalpy, sublimation enthalpy, saturated vapor pressure, fragment for additive scheme.

\section{Introduction}

The utilization of peroxide containing carboranes derivatives as the initiators of radical polymerization or structural agents allows to increase the polymer stability up to thermal and thermooxidizing destruction and to UV and $\gamma$-rays.

The specific structure of the carboranes and their derivatives provides the high enthalpies of isomerization and substantial differences in the values of increments of the same groups to the formation enthalpy of ortho-, metaand para-isomers. Moreover, the substantial differences of inputs of the same substitutes into the enthalpy of formation of carborane and hydrocarbon derivatives have been noticed. At the same time, the values of the enthalpies of vaporization and sublimation have not been analyzed yet.

The enthalpies of vaporization, sublimation and fusion were measured for the following three pairs of peroxide ethers of ortho- and meta- carboranes-12:

(I cr.) 3-methyl-3-(o-carboranoilperoxy)-1-butyne

(II cr.) 3-methyl-3-( $m$-carboranoilperoxy)-1-butyne $\mathrm{HC} \equiv \mathrm{CC}\left(\mathrm{CH}_{3}\right)_{2} \mathrm{OOC}(\mathrm{O}) \mathrm{CB}_{10} \mathrm{H}_{10} \mathrm{CH}$,

(III liq.) 3-methyl-3-(2-isopropyl-o-carboranoilperoxy)1-butyne
(IV cr.) 3 -methyl-3-(7-isopropyl-m-carboranoilperoxy)1-butyne

$\mathrm{HC} \equiv \mathrm{CC}\left(\mathrm{CH}_{3}\right)_{2} \mathrm{OOC}(\mathrm{O}) \mathrm{CB}_{10} \mathrm{H}_{10} \mathrm{CCH}\left(\mathrm{CH}_{3}\right)_{2}$,

(V cr.) tert-butyl peroxyester $o$-carborane-1-carboxylic acid

(VI cr.) tert-butyl peroxyester $m$-carborane-1-carboxylic acid

$$
\mathrm{HCB}_{10} \mathrm{H}_{10} \mathrm{CC}(\mathrm{O}) \mathrm{OOC}\left(\mathrm{CH}_{3}\right)_{3}
$$

\section{Experimental}

Peroxyesters I-IV were obtained by the interaction of 3-methyl-3-hydroperoxy-1-butyne with chloroanhydrides of $o-, m$-carborane-1-carboxylic acid in a methylene chloride in the presence of pyridine (mole ratio of hydroperoxide : chloroanhydride : pyridine $1.1: 1.0: 1.1$ ] [1]. Peroxyesters V and VI were synthesized by the reaction of tert-butyl hydroperoxide with chloroanhydrides of $o-, m$-carborane-1-carboxylic acid in the presence of pyridine in the ethyl ether [2].

The crystalline peroxides were purified by a low temperature recrystallization, while the liquid ones were purified by chromatography on silicagel.

The products were characterized by elemental analyses for carbon, hydrogen, boron and active oxygen; their molecular weights were determined by cryoscopy, and their IR, UV and NMR spectra were recorded. The individual character of the compounds was proved by a thin-layer chromatography on Silufol UV-254 plates.

The purity of compounds was checked by a highpressure liquid chromatography with the use of a system consisting of a pump, UV and refractometric detectors, and a Separon SGX CN column (length $150 \mathrm{~mm}$ and diameter $3.3 \mathrm{~mm}$, particle size $7 \mu \mathrm{m}$ ). Isobutylmethylceton was the eluent. The content of the major component was no less than $99.2 \mathrm{wt} \%$ in all the compounds studied. We were unable to determine the nature of impurities. 
The temperature dependencies of the compound saturated vapor pressure were determined by the Knudsen effusion method. The design of the experimental unit, the reliability of its operation and the procedure for measurements were reported in [3]. For each compound, a series of 6-13 experiments was performed. Volatile impurities could substantially distort the results and were therefore removed at the initial stage of measurements.

Table 1

The temperature dependencies of the vapor pressure over peroxide containing carborane derivatives

\begin{tabular}{|c|c|c|c|c|c|}
\hline Compound & $\tau, \mathrm{s}$ & $\Delta m \cdot 10^{3}, \mathrm{~g}$ & $T, \mathrm{~K}$ & $P_{\mathrm{c}}, \mathrm{Pa}$ & $P, \mathrm{~Pa}$ \\
\hline I & $\begin{array}{c}7201.1 \\
7203.1 \\
7200.2 \\
10801.4 \\
7261.6 \\
7202.5 \\
7200.8\end{array}$ & $\begin{array}{l}0.970 \\
1.875 \\
1.875 \\
5.450 \\
3.665 \\
3.640 \\
3.650\end{array}$ & $\begin{array}{l}318.3 \\
323.1 \\
323.1 \\
328.5 \\
328.5 \\
328.5 \\
328.5\end{array}$ & $\begin{array}{l}0.1324 \\
0.2564 \\
0.2578 \\
0.5037 \\
0.5039 \\
0.5045 \\
0.5060\end{array}$ & $\begin{array}{l}0.1509 \\
0.2922 \\
0.2939 \\
0.5743 \\
0.5744 \\
0.5752 \\
0.5769\end{array}$ \\
\hline II & $\begin{array}{c}21601.2 \\
14401.0 \\
7201.2 \\
7201.2 \\
7203.2 \\
25294.0 \\
7200.0\end{array}$ & $\begin{array}{l}0.600 \\
1.545 \\
1.350 \\
1.400 \\
2.750 \\
9.675 \\
2.800\end{array}$ & $\begin{array}{l}308.1 \\
318.3 \\
323.2 \\
323.2 \\
328.5 \\
328.5 \\
328.5\end{array}$ & $\begin{array}{l}0.0269 \\
0.1054 \\
0.1856 \\
0.1925 \\
0.3811 \\
0.3819 \\
0.3882\end{array}$ & $\begin{array}{l}0.0306 \\
0.1202 \\
0.2116 \\
0.2195 \\
0.4345 \\
0.4353 \\
0.4426\end{array}$ \\
\hline III & $\begin{array}{ll}7 & 201.1 \\
7 & 202.0 \\
7 & 202.2 \\
7 & 201.4 \\
3 & 671.0 \\
3 & 601.5 \\
3 & 602.1 \\
3 & 602.0 \\
2 & 701.8 \\
2 & 702.0 \\
2 & 701.9 \\
2 & 708.0 \\
1 & 127.0\end{array}$ & $\begin{array}{l}1.215 \\
2.380 \\
2.400 \\
2.400 \\
2.410 \\
3.500 \\
4.040 \\
4.050 \\
4.380 \\
4.500 \\
6.250 \\
6.250 \\
3.485\end{array}$ & $\begin{array}{l}333.3 \\
338.4 \\
338.4 \\
338.4 \\
344.5 \\
347.3 \\
348.6 \\
348.6 \\
351.8 \\
351.8 \\
354.4 \\
354.4 \\
357.0\end{array}$ & $\begin{array}{l}0.1578 \\
0.3115 \\
0.3141 \\
0.3141 \\
0.6243 \\
0.9279 \\
1.0729 \\
1.0756 \\
1.5579 \\
1.6005 \\
2.2313 \\
2.2440 \\
2.9936\end{array}$ & $\begin{array}{l}0.1799 \\
0.3551 \\
0.3581 \\
0.3581 \\
0.7117 \\
1.0579 \\
1.2231 \\
1.2262 \\
1.7761 \\
1.8246 \\
2.5437 \\
2.5582 \\
3.4127\end{array}$ \\
\hline IV & $\begin{array}{l}2702.3 \\
2701.1 \\
2702.0 \\
2700.8 \\
2701.0 \\
1801.5 \\
1801.8\end{array}$ & $\begin{array}{l}1.600 \\
1.650 \\
2.650 \\
2.650 \\
2.650 \\
2.860 \\
2.870\end{array}$ & $\begin{array}{l}333.3 \\
333.3 \\
338.3 \\
338.3 \\
338.4 \\
343.4 \\
343.4\end{array}$ & $\begin{array}{l}0.5539 \\
0.5714 \\
0.9243 \\
0.9246 \\
0.9247 \\
1.5074 \\
1.5124\end{array}$ & $\begin{array}{l}0.6315 \\
0.6514 \\
1.0537 \\
1.0541 \\
1.0542 \\
1.7184 \\
1.7241\end{array}$ \\
\hline V & $\begin{array}{ll}5 & 405.8 \\
5 & 400.1 \\
3 & 661.2 \\
3 & 648.1 \\
2 & 288.3 \\
2 & 280.6\end{array}$ & $\begin{array}{c}2.610 \\
2.625 \\
3.850 \\
8.100 \\
10.950 \\
11.000\end{array}$ & $\begin{array}{l}310.2 \\
310.2 \\
317.0 \\
322.6 \\
328.8 \\
328.8\end{array}$ & $\begin{array}{l}0.4773 \\
0.4805 \\
1.0507 \\
2.2384 \\
4.8702 \\
4.9090\end{array}$ & $\begin{array}{l}0.5441 \\
0.5478 \\
1.1980 \\
2.5517 \\
5.5520 \\
5.5962\end{array}$ \\
\hline VI & $\begin{array}{ll}21 & 602.8 \\
21 & 601.4 \\
21 & 601.4 \\
21 & 601.5 \\
21 & 602.0 \\
21 & 602.2\end{array}$ & $\begin{array}{l}1.160 \\
1.150 \\
1.455 \\
1.455 \\
1.880 \\
1.900\end{array}$ & $\begin{array}{l}294.7 \\
294.7 \\
296.4 \\
296.4 \\
298.3 \\
298.3\end{array}$ & $\begin{array}{l}0.0513 \\
0.0517 \\
0.0649 \\
0.0649 \\
0.0844 \\
0.0853\end{array}$ & $\begin{array}{l}0.0585 \\
0.0590 \\
0.0740 \\
0.0740 \\
0.0950 \\
0.0962\end{array}$ \\
\hline
\end{tabular}


This stage was considered to be complete when the rate of sample evaporation was reproducible to within $1 \%$ at a fixed temperature. The errors in pressure determination, which might be caused by the presence of nonvolatile impurities in amounts up to $0.8 \mathrm{wt} \%$, were within the accuracy of definition. The effused substance mass $\Delta m$ was determined by weighing the effusion cell with the accuracy of $\pm 5 \cdot 10^{-6} \mathrm{~g}$. The temperature was maintained constant with the accuracy of $\pm 0.1 \mathrm{~K}$. The accuracy of determining temperature and effusion duration were $\pm 0.05 \mathrm{~K}$ and $\pm 1 \mathrm{~s}$, respectively.

The enthalpies of fusion at atmospheric pressure were determined on a Perkin-Elmer DSC-1B differential scanning calorimeter. The temperature range of calorimeter operation was $315-450 \mathrm{~K}$, the rate of scanning temperature was $4 \mathrm{~K} / \mathrm{min}$, the mean temperature rise created by one scheme signal was $10 \mathrm{~K}$, and the signal duration was 2-3 min.

\section{Results and Discussion}

The results of effusion measurements including saturated vapor pressures $P$ and cell pressures $P$ are listed in Table 1. The temperature dependencies of saturated vapor pressure were processed by the method of least squares and approximated by linear equations $\ln P=A+B / T$. The linear equations coefficients $A$ and $B$, correlation coefficients $\rho$ and the enthalpies of vaporization or sublimation $\Delta_{S(V)} H$ averaged over temperature intervals of measurements $\Delta T$ are listed in Table 2.

The results of DSC measurements of fusion enthalpies are listed in Table 2.

The additivity of evaporation enthalpies of carborane derivatives obtained earlier [4] and the evaporation enthalpies of peroxide containing carboranes presented in this work were verified. For this purpose the vaporization enthalpy inputs of ortho- and meta-carborane-12 nuclei were determined. It was calculated as the difference of vaporization enthalpies between the most reliable literature data [4-5] and data of the corresponding fragments using the Lebedev-Miroshnichenco addittive scheme [6]. The vaporization enthalpies of the substances, fragments and ortho- and meta-carboranes-12 nuclei are presented in Table 3.

To verify the sublimation enthalpies of carborane derivatives additivity we calculated the sublimation enthalpies $(\mathrm{kJ} / \mathrm{mol})$ of groups: $\mathrm{CH}_{3}-10.3, \mathrm{CH}_{2}-8.5$, $\mathrm{COOH}-44.8$ from the data of the alkanes, alcohols and aliphatic acids preliminary [6]. It allowed us to calculate the sublimation enthalpies inputs of ortho- and metacarboranes-12 nuclei by the [4] data (Table 4).

Table 2

Coefficients of the linear approximation of the experimental values describing the temperature dependency of saturated vapor pressures; vaporization, sublimation $\Delta_{S(V)} H$ and fusion $\Delta_{f u s} H$ enthalpies of the studied carborane derivatives

\begin{tabular}{|c|c|c|c|c|c|c|}
\hline Compound & $\Delta T, \mathrm{~K}$ & $A$ & $B \cdot 10^{-2}, \mathrm{~K}$ & $\rho, \%$ & $\Delta_{S(V)} H, \mathrm{~kJ} / \mathrm{mol}$ & $\Delta_{f u s} H, \mathrm{~kJ} / \mathrm{mol}$ \\
\hline I & $318-329$ & $40.87 \pm 0.90$ & $136.1 \pm 2.9$ & 100.00 & $113.1 \pm 2.4$ & 23.3 \\
II & $308-329$ & $39.29 \pm 1.18$ & $131.8 \pm 3.8$ & 99.98 & $109.6 \pm 3.2$ & 29.4 \\
III & $333-357$ & $42.38 \pm 0.65$ & $147.0 \pm 2.3$ & 99.97 & $122.1 \pm 1.9$ & 23.8 \\
IV (liq.) & $333-343$ & $33.12 \pm 0.84$ & $111.9 \pm 2.8$ & 99.95 & $93.0 \pm 2.4$ & - \\
V & $310-329$ & $40.74 \pm 1.96$ & $128.3 \pm 6.2$ & 99.92 & $106.7 \pm 5.2$ & 11.9 \\
VI & $295-298$ & $37.33 \pm 1.10$ & $118.4 \pm 3.3$ & 99.76 & $98.4 \pm 2.7$ & 10.9 \\
\hline
\end{tabular}

The vaporization enthalpies of the substances $\Delta_{V} H$, fragments $\Delta_{V} H_{f r}$ and ortho and meta-carboranes-12 nuclei $\Delta_{V} H_{N}$

\begin{tabular}{|c|c|c|c|c|c|c|}
\hline \multirow[t]{2}{*}{ No. } & \multirow{2}{*}{ Substances } & \multicolumn{2}{|c|}{$\Delta_{V} H, \mathrm{~kJ} / \mathrm{mol}$} & \multirow{2}{*}{$\begin{array}{c}\Delta_{V} H_{f \mathrm{r}}, \mathrm{kJ} / \mathrm{mol} \\
{[6]}\end{array}$} & \multicolumn{2}{|c|}{$\Delta_{V} H_{N}, \mathrm{~kJ} / \mathrm{mol}$} \\
\hline & & ortho- & meta- & & ortho- & meta- \\
\hline $1-2$ & $i-\mathrm{C}_{3} \mathrm{H}_{7} \mathrm{C}_{2} \mathrm{~B}_{10} \mathrm{H}_{11}$ & $69.3 \pm 1.9$ & $63.5 \pm 1.7$ & 13.9 & 55.4 & 49.6 \\
\hline $3-4$ & $i-\mathrm{C}_{3} \mathrm{H}_{5} \mathrm{C}_{2} \mathrm{~B}_{10} \mathrm{H}_{11}$ & $75.4 \pm 1.6$ & $62.09 \pm 0.33$ & 14.90 & 60.5 & 47.2 \\
\hline $5-6$ & $n-\mathrm{C}_{4} \mathrm{H}_{9} \mathrm{C}_{2} \mathrm{~B}_{10} \mathrm{H}_{11}$ & $77.3 \pm 3.7$ & $67.7 \pm 0.8$ & 20.7 & 56.6 & 47.0 \\
\hline $7-8$ & $i-\mathrm{C}_{4} \mathrm{H}_{9} \mathrm{C}_{2} \mathrm{~B}_{10} \mathrm{H}_{11}$ & $72.8 \pm 2.1$ & $64.1 \pm 2.8$ & 18.7 & 54.1 & 45.4 \\
\hline $9-10$ & $n-\mathrm{C}_{5} \mathrm{H}_{11} \mathrm{C}_{2} \mathrm{~B}_{10} \mathrm{H}_{11}$ & $84.3 \pm 6.0$ & $74.6 \pm 2.4$ & 25.4 & 58.9 & 49.2 \\
\hline $11-12$ & $n-\mathrm{C}_{6} \mathrm{H}_{13} \mathrm{C}_{2} \mathrm{~B}_{10} \mathrm{H}_{11}$ & $93.5 \pm 2.5$ & $79.8 \pm 2.9$ & 30.2 & 63.6 & 49.6 \\
\hline 13 & $n-\mathrm{C}_{8} \mathrm{H}_{17} \mathrm{C}_{2} \mathrm{~B}_{10} \mathrm{H}_{11}$ & $92.5 \pm 3.0$ & - & 39.8 & 52.7 & - \\
\hline \multicolumn{5}{|c|}{ Average } & $57.4 \pm 3.5$ & $48.0 \pm 1.8$ \\
\hline
\end{tabular}


The sublimation enthalpies of the substances $\Delta_{S} H$, and ortho- and meta-carboranes-12 nuclei $\Delta_{S} H_{N}$

\begin{tabular}{|c|c|c|}
\hline \multirow{2}{*}{ Substances } & $\Delta_{S} H$ & $\Delta_{S} H_{N}$ \\
\cline { 2 - 3 } & \multicolumn{2}{|c|}{$\mathrm{kJ} / \mathrm{mol}$} \\
\hline $\mathrm{CH}_{3}-o-\mathrm{C}_{2} \mathrm{~B}_{10} \mathrm{H}_{11}$ & $63.8 \pm 0.6$ & 53.5 \\
\hline $\mathrm{CH}_{3}-m-\mathrm{C}_{2} \mathrm{~B}_{10} \mathrm{H}_{11}$ & $60.7 \pm 0.6$ & 50.4 \\
\hline HOOC-o- $\mathrm{C}_{2} \mathrm{~B}_{10} \mathrm{H}_{11}$ & $97.1 \pm 0.7$ & 52.3 \\
\hline HOOC- $m-\mathrm{C}_{2} \mathrm{~B}_{10} \mathrm{H}_{11}$ & $97.7 \pm 0.7$ & 52.9 \\
\hline$\left(\mathrm{CH}_{3}\right)_{2}-o-\mathrm{C}_{2} \mathrm{~B}_{10} \mathrm{H}_{10}$ & $65.3 \pm 0.7$ & 44.7 \\
\hline$\left(\mathrm{CH}_{3}\right)_{2}-m-\mathrm{C}_{2} \mathrm{~B}_{10} \mathrm{H}_{10}$ & $58.1 \pm 0.7$ & 37.5 \\
\hline Average & & $48.6 \pm 6.7$ \\
\hline
\end{tabular}

Table 5

The input data of some groups, nuclei in vaporization and sublimation enthalpies of peroxide containing derivatives carborane-12

\begin{tabular}{|c|c|c|c|}
\hline \multicolumn{4}{|c|}{ Vaporization } \\
\hline Inputs & ortho-carborane & meta-carborane & Other compounds \\
\hline carborane-12 nuclei & 57.4 & 48.0 & - \\
\hline $\mathrm{HC} \equiv \mathrm{C}\left(\mathrm{CH}_{3}\right)_{2} \mathrm{COO}(\mathrm{CO})$ & $32.4^{1}$ & $32.2^{I I}$ & $36.0^{17}$ \\
\hline$\left(\mathrm{CH}_{3}\right)_{3} \mathrm{COO}(\mathrm{CO})$ & $37.4^{\mathrm{v}}$ & $39.5^{\mathrm{VI}}$ & $\begin{array}{l}38.9^{14} \\
41.7^{15}\end{array}$ \\
\hline$i-\mathrm{C}_{3} \mathrm{H}_{7}$ & $8.6^{\mathrm{III}}$ & $12.8^{\mathrm{IV}}$ & $\begin{array}{l}11.9^{1} \\
15.5^{2}\end{array}$ \\
\hline \multicolumn{4}{|c|}{ Sublimation } \\
\hline carborane-12 nuclei & 52.9 & 51.7 & - \\
\hline $\mathrm{HC} \equiv \mathrm{C}\left(\mathrm{CH}_{3}\right)_{2} \mathrm{COO}(\mathrm{CO})$ & $60.2^{\Gamma}$ & $57.9^{\mathrm{II}}$ & - \\
\hline$\left(\mathrm{CH}_{3}\right)_{3} \mathrm{COO}(\mathrm{CO})$ & $53.8^{\mathrm{V}}$ & $46.7^{\mathrm{VI}}$ & $\begin{array}{l}51.0^{15} \\
47.1^{16} \\
\end{array}$ \\
\hline$i-\mathrm{C}_{3} \mathrm{H}_{7}$ & $9.1^{\mathrm{III}}$ & - & - \\
\hline
\end{tabular}

Note: The superscripts on the sublimation and evaporation enthalpies of fragments mark the number of compounds, on which these fragments are defined [Roman numeral - from the data of this work (Table 2), and Arabic numerals - from the data of other authors (Tables 3,6)].

Table 6

The vaporization and sublimation enthalpies of compounds, taken for comparative calculation of some group inputs

\begin{tabular}{|c|c|c|c|}
\hline \multirow{2}{*}{ No. } & \multirow{2}{*}{ Substances } & $\Delta_{V} H$ & $\Delta_{S} H$ \\
\cline { 3 - 4 } & & \multicolumn{2}{|c|}{$\mathrm{kJ} / \mathrm{mol}$} \\
\hline 14 & $\left(\mathrm{CH}_{3}\right)_{3} \mathrm{COO}(\mathrm{CO}) \mathrm{C}_{6} \mathrm{H}_{5}$ (liq.) & $72.73 \pm 0.41$ & - \\
\hline 15 & $\mathrm{~m}-\left[\left(\mathrm{CH}_{3}\right)_{3} \mathrm{COO}(\mathrm{CO})\right]_{2} \mathrm{C}_{6} \mathrm{H}_{4}$ (cr.) & $117.2 \pm 4.0$ & $139.5 \pm 4.0$ \\
\hline 16 & $\left(\mathrm{CH}_{3}\right)_{3} \mathrm{COO}(\mathrm{CO})-\left(\mathrm{CH}_{2}\right)_{4}-(\mathrm{CO}) \mathrm{OOC}\left(\mathrm{CH}_{3}\right)_{3}$ (cr.) & - & $128.2 \pm 2.1$ \\
\hline 17 & $\mathrm{HC} \equiv \mathrm{C}\left(\mathrm{CH}_{3}\right)_{2} \mathrm{COO}(\mathrm{CO}) \mathrm{C}_{6} \mathrm{H}_{5}$ (liq. $)$ & $69.8 \pm 1.2$ & - \\
\hline
\end{tabular}


As seen from Tables 3 and 4 the obtained values of vaporization and sublimation enthalpies of ortho- and metacarboranes-12 nuclei are not differentiable at the limiting error of measurements for all compounds. It serves an evidence of the additivity of vaporization and sublimation enthalpies of carborane derivatives under investigation and permits to theoretically calculate the vaporization and sublimation enthalpies inputs of our carborane-containing peroxides.

The results of calculation show that the input data of $\mathrm{HC} \equiv \mathrm{CC}\left(\mathrm{CH}_{3}\right)_{2} \mathrm{OOC}(\mathrm{O}),\left(\mathrm{CH}_{3}\right)_{3} \mathrm{COO}(\mathrm{CO})$ and $i-\mathrm{C}_{3} \mathrm{H}_{7}$ groups in vaporization and sublimation enthalpies of orthoand meta-carboranes- 12 are not differentiable and coincide with the same values in another compounds (Table 5). The vaporization and sublimation enthalpies of four compounds, taken from $[7,8]$ for comparative calculation of fragments are presented in Table 6 .

\section{Conclusions}

Therefore, it was determined that vaporization and sublimation enthalpies of all studied so far carborane derivatives (including peroxides) are additive. It provides the possibility to calculate the enthalpies characteristics via additive schemes.

The obtained results confirm the additivity of intermolecular interactions and also confirm the nonadditivity intrarmolecular interactions of carborane derivatives.

\section{References}

[1] Zvereva T., Yuvchenko A. and Zhukovskaya N.: Russ. Zh. Org. Khim., 1992, 62, 143.

[2] Ol'dekop Yu., Churkina L. and Zvereva T.: Russ. Zh. Org. Khim., 1978, 48, 574.

[3] Dibrivnyi V., Lutsiv G. and Van-Chin-Syan Yu.: Russ. Zh. Fiz. Khim., 1999, 73, 2254.

[4] Gal'chenko G.: [in:] Gerasimov Ya. and Akishin P. (Eds.), Khimicheskaya Termodinamika. Izd-vo Mosk. Gos. Univ., Moskwa 1984.

[5] Tamm N.: PhD thesis. Moskovsky Gosudarstvenny Universitet, Moskwa 1994.

[6] Lebedev Yu. and Miroshnichenko E.: Termokhimiya Ispareniya Organicheskih Soedinenij. Nauka, Moskwa 1981.

[7] Van-Chin-Syan Yu.: Doctoral thesis. Moskovsky Gosudarstvenny Universitet, Moskwa 1986.

[8] Chickoks J. and Acree W.: J. Phys. Chem., 2003, 32, 519.

\section{ЕНТАЛЬПЇВИПАРОВУВАННЯ ТАСУБЛІМАЦЇ̈ ШЕСТИПЕРОКСИВМІСНИХПОХІДНИХ КАРБОРАНІВ-12}

Анотація. На базі температурних залежностей тиску насиченої пари, виміряних ефузійним методом Кнудсена, визначено ентальпї випаровування та сублімації шести пероксивмісних похідних карборанів. Ентальпії плавлення встановлено методом ДСК. Визначено внески карборанових ядер та інкременти груп-замісників атома водню в карборанах.

Ключові слова: карборани, ентальпія випаровування, ентальпія сублімачї̈, тиск насиченої пари, фрагменти для адитивної схеми. 